Collection: INCOTW - Sassari, Italy (2017)

"International Congress on Cork Oak Trees and Woodlands"

Guest Editors: Piermaria Corona, Sandro Dettori

\title{
Indicators for the assessment and certification of cork oak management sustainability in Italy
}

\author{
Martina Pollastrini ${ }^{(1-2)}$, \\ Ugo Chiavetta ${ }^{(1)}$, \\ Andrea Cutini ${ }^{(1)}$, \\ Antonio Casula ${ }^{(3)}$, \\ Sara Maltoni ${ }^{(3)}$, \\ Sandro Dettori ${ }^{(4)}$, \\ Piermaria Corona ${ }^{(1)}$
}

\begin{abstract}
Sustainable forest management (SFM) is crucial for forest ecosystem productivity and conservation, especially in systems such as cork oak (Quercus suber L.) threatened by human activities and biotic and abiotic factors. In this study SFM indicators with particular reference to cork oak forests in the region of Sardinia (Italy) are proposed and tested. Sustainable and responsible management options specifically aimed at cork oak forest management and chain of custody certification are also provided. A set of ten indicators was proposed and assessed by an expert panel in cork oak management. Five indicators were also tested against data on structure, origin, health condition and management in $\mathbf{2 8 5}$ forest compartments managed by FoReSTAS (Regional Forest Agency for Land and Environment of Sardinia, Italy), including 361 sampling plots and 5345 trees. In order to investigate the priorities and perceptions of SFM experts and stakeholders, a survey was also carried out by completion of a questionnaire on the technical issues of cork oak woodland management. The sur vey results highlighted a need to improve environmental and economic perfor mance by means of SFM and certification. The indicators tested in Sardinian cork oak woodlands showed that about $80 \%$ of the stands fulfilled management sustainability requirements. The suggested SFM indicators can effectively support proactive management and conservation measures, representing a valuable tool in the current context of growing environmental and socioeconomic awareness.
\end{abstract}

Keywords: Quercus suber, Sustainable Forest Management, Forest Management Planning, Non-wood Forest Products, Sardinia, Italy

servation tool based on a third-party assessment of compliance with sustainable environmental and socio-economic management standards. SFM is particularly important in Mediterranean forest ecosystems, such as cork oak (Quercus suber L.) woodlands, where a strong human influence, related to past and present management activities, has shaped forest structure, productivity, species diversity, evolution and regeneration (Palahi et al. 2008).

Human management of cork oak woodlands has favored habitat heterogeneity and biodiversity at local and regional levels.
The open canopy structure, where tree density may be as low as 60 trees per hectare, and the shrubland-grassland mosaic of managed cork oak forests, intermixed with the closed canopy of evergreen trees, favor high plant and animal species richness. Cork oak savanna-type ecosystems (named montado, dehesa, azaghar, pascolo arborato, meriagos in Portugal, Spain, North Africa, Italy and Sardinia, respectively) are protected under the Pan-European network of protected areas ( $\mathrm{Na}$ tura 2000) and defined as "biodiversitybased product systems" by the Convention

(1) CREA, Research Centre for Forestry and Wood, v.le Santa Margherita 80, I-52100, Arezzo (Italy); (2) Università degli Studi di Firenze, Dipartimento di Scienze delle Produzioni Agroalimentari e dell'Ambiente, p.le delle Cascine 28, I-50144 Firenze (Italy); (3) Agenzia Forestale Regionale per lo Sviluppo del Territorio e dell'Ambiente della Sardegna (FoReSTAS), v.le Merello 86, I-09123 Cagliari (Italy); (4) Università degli Studi di Sassari, Dipartimento Scienza della Natura e del Territorio, v. De Nicola, I-07100 Sassari (Italy)

@ Martina Pollastrini (martpollas@gmail.com)

Received: Aug 07, 2017 - Accepted: Aug 27, 2018

Citation: Pollastrini M, Chiavetta U, Cutini A, Casula A, Maltoni S, Dettori S, Corona P (2018). Indicators for the assessment and certification of cork oak management sustainability in Italy. iForest 11: 668-674. - doi: 10.3832/ifor2587-011 [online 2018-10-04] 
on Biological Diversity. Cork oak woodlands are characterized by a structure that may be referred to as "one system, multiple land uses" (Bugalho et al. 2009), i.e., jointly delivering various provisioning, regulating and cultural services (Palahi et al. 2008).

Cork oak is an evergreen species mainly distributed in the Western Mediterranean basin, from the Iberian peninsula (Portugal, Spain) and North Africa (Morocco, Algeria, Tunisia) to Corsica and Italy, covering 2.1 million hectares (APCOR 2015). In Italy cork oak forests cover a total of 186,344 ha (1.78 $\%$ of the total forest area - INFC 2007), of which 168,602 ha are cork oak-dominated high forests and 17,742 ha open formations, with small groups of cork oak trees mixed with other tree species. At the subnational level, cork oak woodlands are mainly concentrated in Sardinia, where they cover 139,489 ha (INFC 2007) and can be classed as pure stands with more than $25 \%$ canopy cover $(80,489$ ha - RAS 2008$)$ and mixed stands $(57,934$ ha) with $5-25 \%$ canopy cover, where cork oak is the dominant species associated with other tree species and with agro-silvopastoral systems. The third cork oak forest type, according to INFC 2007, is represented by broadleaf forests with a sporadic presence of cork oak trees (489,877 ha in Sardinia). In Italy, cork oak forests are also present in
Tuscany $(6,142$ ha concentrated along the Tyrrhenian coast), Latium (2,211 ha), Calabria (4,851 ha) and Sicily (15,541 ha - INFC 2007).

Features and management of cork oak ecosystems are dependent on the distinctive trait of cork oak, i.e., its bark. In Italy, cork collection is practised at 9-12 year intervals, corresponding to the average time necessary for the trees to produce a new bark layer approximately 30-40 mm thick. Cork yield is determined by the circumference of the tree stem, the harvesting frequency and the length of stem and main branches that can be stripped. In Italy the first cork harvest is carried out when the tree is approximately 30-50 years old or when it reaches a conventional size $(60 \mathrm{~cm}$ of stem circumference over the bark at $1.30 \mathrm{~m}$ of height, according to the national law n.759/1956 and the regional law in Sardinia - RAS 1994). In the western Mediterranean basin 300,000 tons of cork are harvested annually, $70 \%$ of which is transformed into bottle stoppers (Aronson et al. 2009, Bugalho et al. 2011). Other minor products include floor and wall tiles, insulation material, sound-proofing in the car industry, special devices for the space industry, accessories or handicrafts.

The conservation and restoration of cork oak woodlands and implementation of sustainable management actions may be ad-
Fig. 1 - Map of the forests used for testing SFM indicators in Sardinia (Italy).

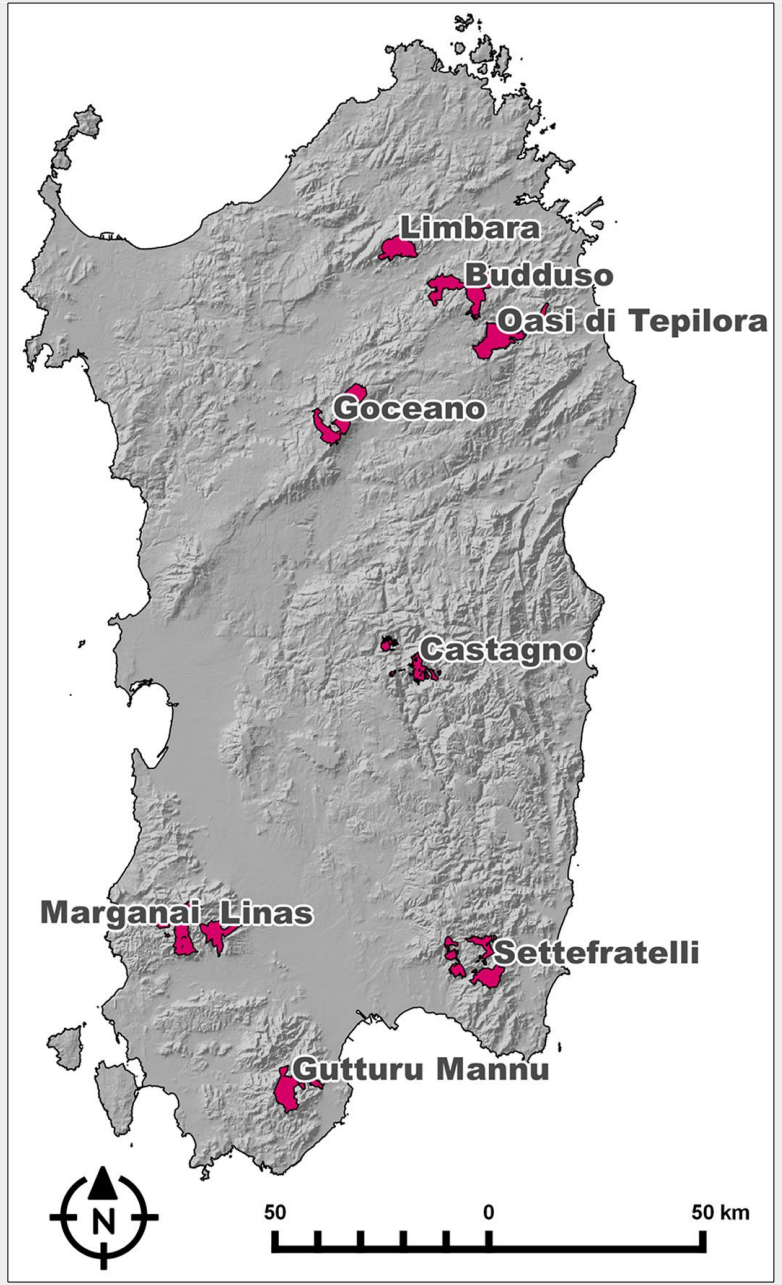

dressed by means of market tools such as "payment for ecosystem services" and/or certification of forest management and chain of custody ( $\mathrm{COC}$, i.e., the pathway that leads from raw materials, through processing to final products, from the forest to the consumer), such as the Forest Stewardship Council (FSC) and Programme for the Endorsement of Forest Certification (PEFC) schemes. FSC certification for cork oak forest management is currently adopted in Portugal, Spain and Italy with 357,386, 159,695 and 66 certified hectares, respectively (Dalla Vecchia \& Pettenella 2017), and is underway in Morocco and Tunisia. PEFC certification currently applies in cork oak forests in Portugal and Spain, for 109,058 and 21,000 ha, respectively (Brunori et al. 2017). In Italy three public forests (over 8,000 ha, including cork oak woodlands) managed by the Regional Forest Agency for Land and Environment of Sardinia (FoReSTAS) were FSC-certified for forest management and $\mathrm{CoC}$ of firewood in the years 2011-2014. The only forest with a valid FSC certificate in Sardinia since 2010 is represented by 66 ha of semi-natural cork forests owned by the public agency AGRIS Sardegna, Department of Research for cork and silviculture, located in Tempio Pausania (province of Olbia-Tempio). For PEFC, a private forest (20 ha) owned by Società Agricola Limbara s.r.l. of Calangianus (Olbia-Tempio) was certified for the years 2008-2013 (PEFC Italy 2015).

Certification may provide an added value to the final products, while safeguarding commercial rights of local communities and increasing economic benefits. However, limited knowledge on sustainable cork oak management practices hinders the application of good practices and SFM indicators. In this light and with a view to filling these knowledge gaps, this study aimed to: (i) propose a set of SFM indicators specifically targeting cork oak forests using structural, management and economic information obtained from forest management plans in Sardinia; (2) define sustainable and responsible cork oak woodland management options and strategies oriented towards cork oak forest management and CoC certification.

\section{Material and methods}

\section{Development of the indicators}

A set of ten SFM indicators specific for cork oak forests was defined (Tab. S1 in Supplementary material) and tested using data and information on structure, origin, health condition and management of cork oak stands obtained from the forest management plans of FoReSTAS' estates (2014).

The indicators proposed for cork oak forests were conceived as forest management "performance indicators", referred to aspects for which binding thresholds (standard values) of forest management sustainability were applied. All the indica- 
tors proposed, along with the relative thresholds were partly derived from the literature (Cañellas \& Montero 2002, Barberis et al. 2003, Agnoletti et al. 2004, Costa \& Pereira 2010, Pizzurro et al. 2010, Oliveira \& Costa 2012, Camilo-Alves et al. 2013), technical guidelines (DGRF 2005, FSC Portugal 2012, PEFC Italy 2015) normative references (RAS 1994), and checked and discussed by a panel of experts in SFM, cork oak management, forest certification, cork production, forest resources' protection and conservation, working in both public and private sectors.

The indicators were identified by taking into account the management issues and ecological features of cork oak woodlands. The feasibility of obtaining indicators from management planning data was also assessed.

\section{Questionnaire survey}

A survey to investigate the perception and priorities of stakeholders and experts on cork oak woodlands SFM was carried out. A questionnaire was drawn up and distributed to national and international stakeholders. Eleven questions concerning SFM and technical information on management of cork oak stands, plus two questions on the education level and professional specialization of the interviewees, were asked. The respondents were asked to express their preference on the issues considered, by ranking the answers. The questionnaire was presented at the International Congress on Cork Oak Trees and Woodlands and $3^{\circ}$ National Congress of Cork (25-26 May 2017, Sassari, Italy) and was completed anonymously either on paper or online. A total of 34 persons responded to the questionnaire. The respon- dents (23 males and 11 females) were from Italy, Portugal and Spain. Concerning their job positions, 10 were officials/technologists, 18 researchers/scientists and 6 technicians. They were all (except one person) experienced and specialized in SFM; 28 persons usually and/or occasionally work in cork oak management, while 6 were only theoretically well-informed and/or inexperienced on this specific issue.

\section{Field test}

A sub-set (five) of indicators were tested in nine Sardinian forests (Fig. 1), including cork oak woodlands managed by the public agency FoReSTAS, for a total of 2267 ha of cork oak forests (Tab. 1). The sub-set of indicators was tested in 285 forest compartments ( $2 \%$ of the Sardinian cork oak forests), on 361 sampling plots (circular plots with radius of $13 \mathrm{~m}$ ) for a total of 5345 cork oak trees surveyed. The indicators tested were: first (indicator 3.1) and next (indicator 3.2) extraction height; minimum circumference at $1.30 \mathrm{~m}$ of height $(\mathrm{CBH})$ for the first cork extraction (indicator 4); age/size classes (indicator 9.1); vegetation cover (indicator 9.2). Indicators 3.1, 3.2 and 4 were assessed at tree and sampling plot levels, while indicators 9.1 and 9.2 were assessed at the compartment level.

\section{Results}

\section{Survey on SFM of cork oak woodlands}

The results of the questionnaire are shown in Fig. 2, Fig. 3 and Fig. 4. The need to improve the environmental quality of cork oak stands and to increase their economic revenue by means of SFM certification is highlighted (Fig. 2B and Fig. 2F). Im- portant limiting factors for cork extraction are forest health and vitality and the protective functions of forests ( $20 \%$ of the responses quote "moderately limiting factor" - Fig. 3A). The general perception on the current conditions of cork oak woodlands is that they need slight improvement to achieve management sustainability ( $80 \%$ of the responses - Fig. 2F). The main criteria to achieve this goal are to improve forest health and vitality (44\% of responses as "very important" - Fig. 3B), biological diversity (32\% of responses as "very important") and socio-economic functions of cork oak stands ( $24 \%$ of responses as "very important"). A reduction in cork extraction height below 2.5 times the CBH (Fig. 2C) and an increase in the $\mathrm{CBH}$ over $60 \mathrm{~cm}$ for the first cork extraction (Fig. 2D) are considered to slightly improve the sustainability of the management. The use of only natural regeneration is considered to improve management sustainability (Fig. 2E), as well as an increase of understory cover (Fig. 4A) and limitation of mechanical operations in stands with a slope higher than 15\% (Fig. 4B). Finally, heterogeneous stand structures (Fig. 4C) are perceived as relatively more sustainably managed than homogenous ones.

\section{Field test of sustainability indicators}

As for the evaluation of the "first extraction height" (indicator 3.1), the test in Sardinian cork oak forests shows that 3.3\% of cork oak trees do not comply with the proposed threshold. Plots that do not comply with this indicator, are $10.9 \%$ and $4.7 \%$ containing a number of trees out of standard of at least $5 \%$ and $20 \%$, respectively.

With regard to the indicator 3.2 ("next extraction height"), the test shows that $0.7 \%$

Tab. 1 - Structural and management characteristics of the forests used to test a subset of SFM indicators of specific for cork oak forests in Sardinia. (Mean CBH): mean stem circumference at breast height (1.30 m above ground); (Regeneration): regeneration of the stands, which can be natural, either by seed or agamic (i.e., through sprouts after cutting), artificial (planting) or both (mixed). (Average slope): assessed by weighted mean over areas with different slope within the considered stand; (Cork production): low $<100 \mathrm{~kg} \mathrm{ha}^{-1} \mathrm{yr}^{-1}$; average, 100-200 kg ha-1 $\mathrm{yr}^{-1}$; high >200 kg ha-1 $\mathrm{yr}^{-1}$.

\begin{tabular}{|c|c|c|c|c|c|c|c|c|c|}
\hline $\begin{array}{l}\text { Forest } \\
\text { district }\end{array}$ & Municipality & $\begin{array}{l}\text { Cork oak } \\
\text { forest } \\
\text { area (ha) }\end{array}$ & $\begin{array}{c}\text { Cork oak } \\
\text { density } \\
\left.\text { (tree ha }{ }^{-1}\right)\end{array}$ & $\begin{array}{c}\text { Mean } \\
\text { CBH }(\mathrm{cm})\end{array}$ & $\begin{array}{l}\text { Mean } \\
\text { height } \\
(\mathrm{m})\end{array}$ & Regeneration & $\begin{array}{l}\text { Average } \\
\text { canopy } \\
\text { cover (\%) }\end{array}$ & $\begin{array}{l}\text { Average } \\
\text { slope } \\
\text { (\%) }\end{array}$ & $\begin{array}{c}\text { Cork } \\
\text { production }\end{array}$ \\
\hline Buddusò & $\begin{array}{l}\text { Alà dei Sardi, Monti, } \\
\text { Berchidda, Buddusò }\end{array}$ & 338 & 425 & 67.2 & 6.22 & mixed & 43.9 & 12.9 & high \\
\hline Castagno & $\begin{array}{l}\text { Aritzo, Tonara, Belvì, } \\
\text { Sorgono }\end{array}$ & 142 & 620 & 96 & 8.08 & natural & 67 & 37.3 & average \\
\hline Goceano & $\begin{array}{l}\text { Bono, Bottida, Anela, } \\
\text { Bultei }\end{array}$ & 644 & 735 & 80 & 6.39 & $\begin{array}{l}\text { natural } \\
\text { (agamic) }\end{array}$ & 71.6 & 18.6 & average \\
\hline Gutturu Mannu & $\begin{array}{l}\text { Pula, Villa San Pietro, } \\
\text { Domus de Maria, Sarroch }\end{array}$ & 21 & 610 & 72.3 & 6.59 & artificial & 60 & 28.1 & high \\
\hline Limbara & Berchidda & 273 & 630 & 55.1 & 5.31 & natural & 41.4 & 30.3 & high \\
\hline Linas & $\begin{array}{l}\text { Villacidro, Iglesias, } \\
\text { Domuisnovas, } \\
\text { Gonnosfanadiga }\end{array}$ & 315 & 710 & 55.2 & 4.85 & artificial & 56.2 & 32.1 & low \\
\hline Marganai & $\begin{array}{l}\text { Dosmunovas, Iglesias e } \\
\text { Fluminimaggiore }\end{array}$ & 41 & 1240 & 70 & 7.81 & mixed & 87.5 & 30.0 & low \\
\hline Oasi di Tepilora & Bitti, Alà dei Sardi, Torpé & 194 & 620 & 64.7 & 5.60 & mixed & 63.3 & 20.3 & low \\
\hline Settefratelli & Burcei, San Vito, Sinnai & 299 & 1135 & 49 & 5.05 & mixed & 67.7 & 29.3 & average \\
\hline
\end{tabular}



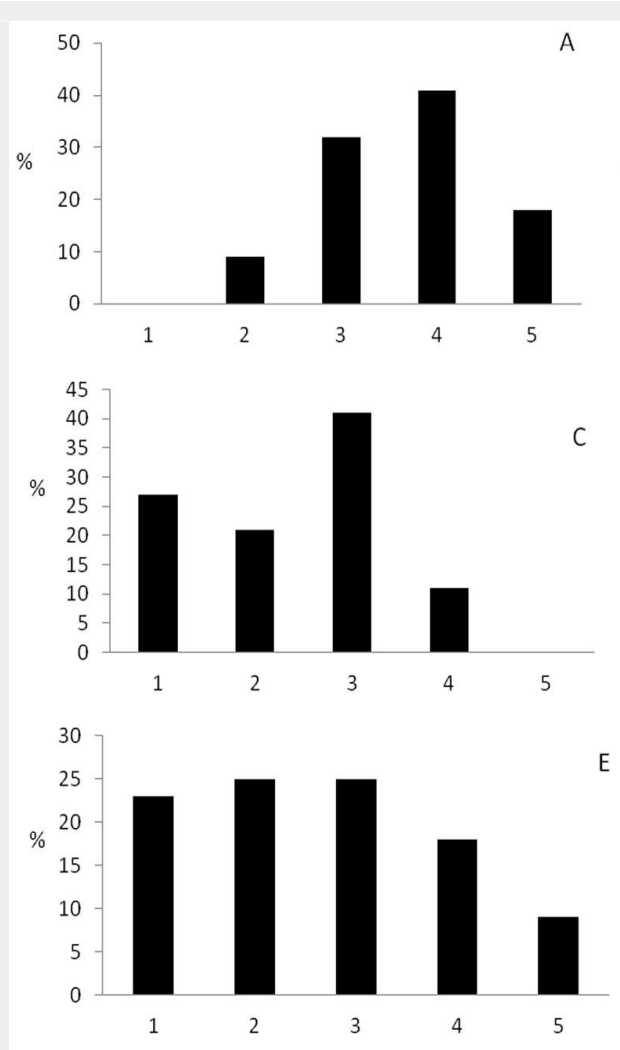

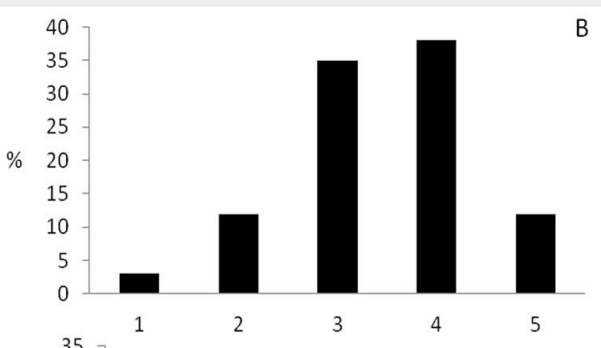

D
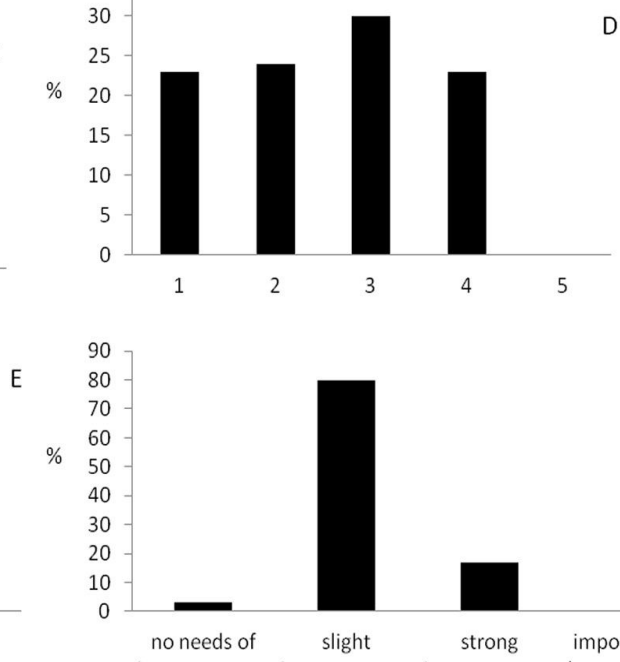

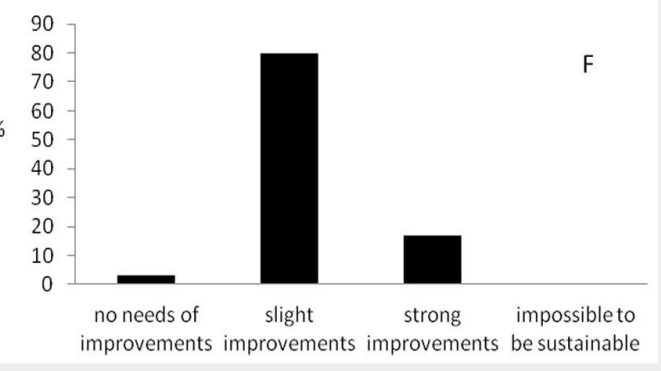

Fig. 2 - Results of the questionnaire on SFM of cork oak forests. Panels (A to F) show the percentage given to each answer type by national and international stakeholders to the following questions: $(A)$ "To what extent can SFM certification of cork oak forests increase environmental quality?"; (B) "To what extent can SFM certification of cork oak forests increase economic revenues?"; (C) "Reduction in cork extraction height below 2.5 times the $\mathrm{CBH}$ improve management sustainability?"; (D) "Can the increase of $\mathrm{CBH}$ over $60 \mathrm{~cm}$ for the first cork extraction improve management sustainability?"; (E) “Can exclusive use of natural regeneration improve management sustainability?"; (F) "Is cork oak management already sustainable?". Under (A-E), (1): cannot improve; (2): improves; (3): slightly improves; (4): moderately improves; (5): strongly improves. of trees and $5.8 \%$ of plots, with at least $5 \%$ extraction height is more than 2.5 times of trees out of standard, do not comply the CBH decreases to $1.8 \%$.

with the proposed standard. If we consider The "minimum circumference over the plots with at least $20 \%$ of trees out of stan- bark at $1.30 \mathrm{~m}$ stem height for the first cork dard, the number of plots where the cork extraction" (indicator 4 ) shows that $8.9 \%$ of cork oaks have been exploited with a circumference lower than $60 \mathrm{~cm}$. Plots out of standard are $26.5 \%$ or $13.5 \%$, if we consider the thresholds of $5 \%$ or $20 \%$ of trees out of standard within each plot, respectively.

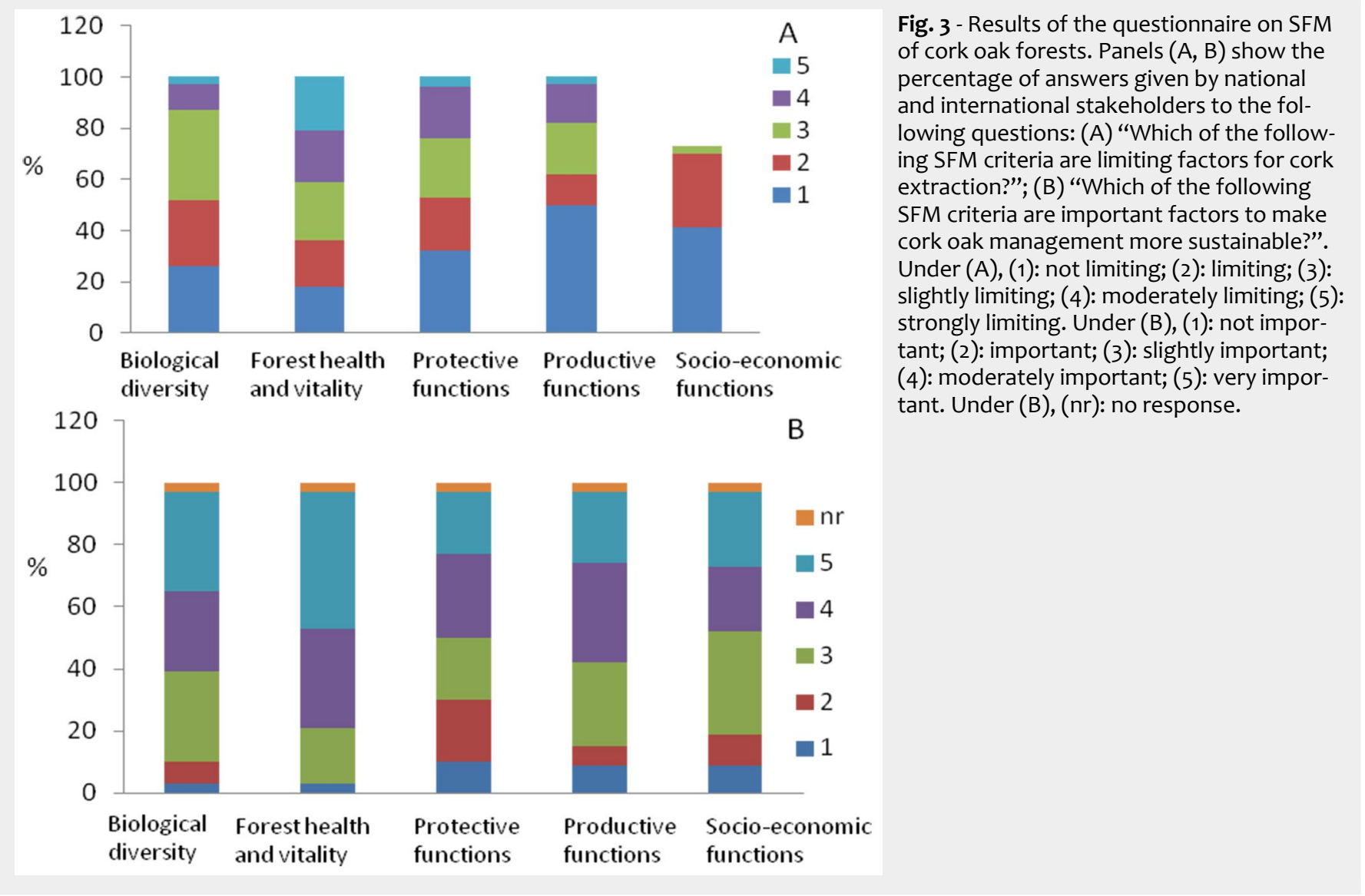


Finally, the indicator "age/size classes" (indicator 9.1) shows that $15.6 \%$ of the cork oak forests considered are out of the standard of 50-1000 cork oaks ha-1 with $\mathrm{CBH}$ higher than $30 \mathrm{~cm}$. A similar number of plots out of standard (15.2\%) was also found for the indicator 9.2 "vegetation cover".

\section{Discussion}

The survey has shown that the most relevant aspects to be considered for sustainable management of cork oak systems are health and vitality of the trees and biological diversity of the stands. Continuous bark stripping may alter tree physiology and damage health if cambial tissues are affected; moreover, intensive pruning and excessive debarking, particularly in young or stressed trees, may cause significant damage (Acácio \& Holmgren 2014). Local forest laws (RAS 1994) or guidelines provided by associations of cork producers (e.g., DGRF 2005 and CPF 2014 in Spain, APCOR 2015 in Portugal) regulate the period and minimum stem size of trees for cork harvesting, cork extraction frequency, the first and next extraction height. However, these parameters often vary among and within countries (e.g., in Spain there are guidelines for cork oak management specific to Catalonia), dispersed and strongly related to traditional rural practices. The latter may not appropriately take into account upcoming issues and possible extreme events, especially those related to climate change (e.g., drought events, insect and pathogen attacks - Costa et al. 2016, Oliveira et al. 2016).

An internationally recognized and well defined set of management models for cork oak woodlands, aimed at reducing their vulnerability and improving their sustainability, is still missing (Sedda et al. 2011, Acácio \& Holmgren 2014). The SFM indicators proposed and tested in this study may contribute towards the recognition of correct management options for cork oak forests, particularly in view of SFM certification. The latter, considers the presence of a management plan as a mandatory requirement, at least at the forest district level, in order to identify, organize and implement management interventions.

The proposed indicators related to cork production (indicators 1-4, 6) aim to avoid tree over-exploitation. Practices such as excessive debarking (i.e., the collection of large amounts of cork per tree), or debarking stressed trees or trees with small stem size at breast height are often driven by unsustainable productive purposes or by unskilled personnel involved in cork harvesting (Catry et al. 2012). Our recommendation to employ experienced personnel in cork extraction (indicator 8.4) aims to ensure, on the one hand, good quality of the work and, on the other, to favor the employment of local people, with positive socio-economic effects.

Appropriate grazing management is es-

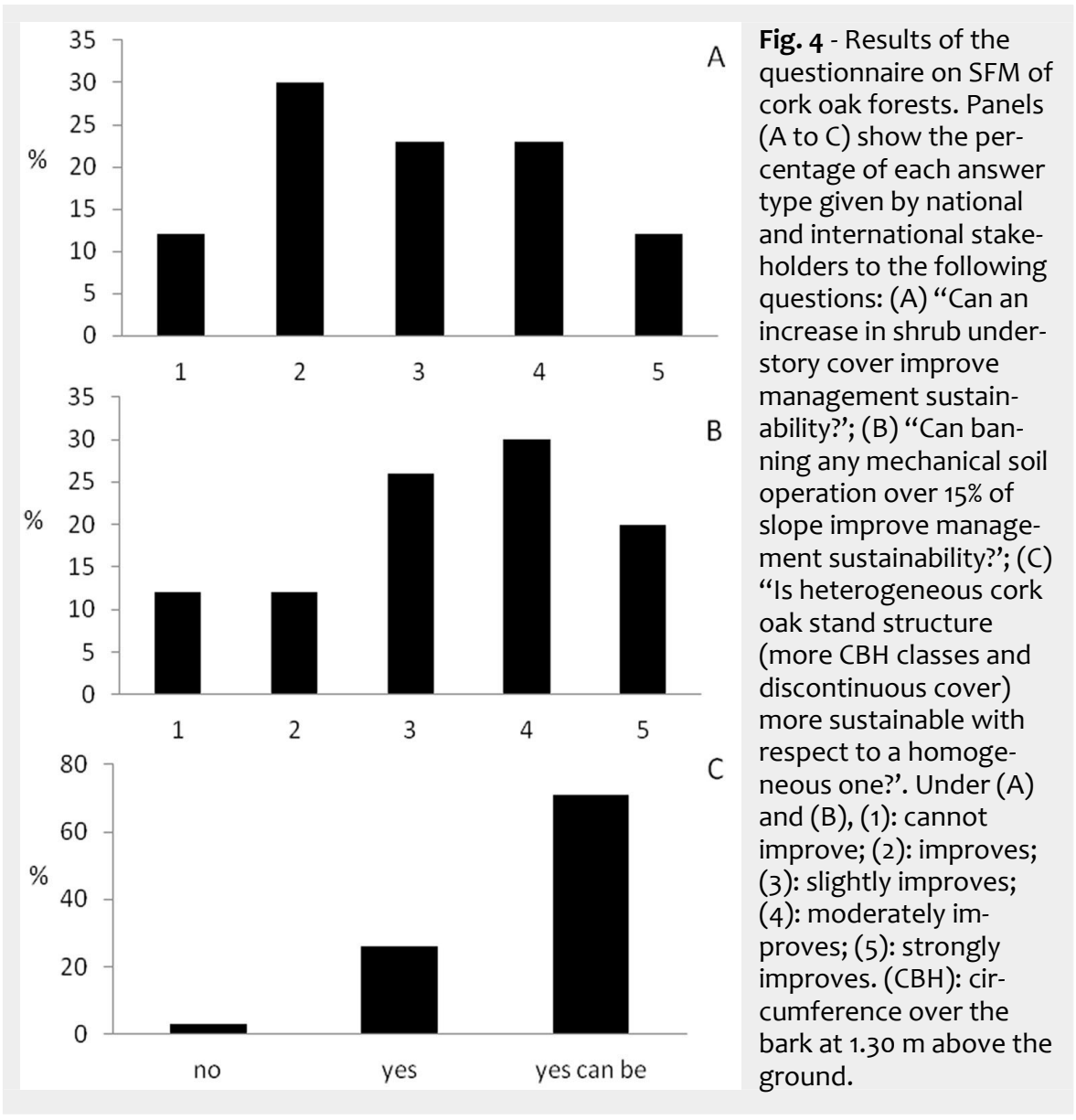

sential for the regeneration and conservation of cork oak stands (Arosa et al. 2017). Besides not always being under appropriate control, grazing is often regulated by local laws that provide generic rules without taking into account the site-specific ecological conditions of cork oak stands and the type and number of grazing animals per unit area. In Sardinia an increase in grazing activities, especially related to sheep-milk production, may have negative effects in this respect (Ruju 2002, Dettori et al. 2001). Hence, suitable grazing regulations (indicator 5) should be included among the management practices to be adopted for sustainable cork oak systems.

Biotic and abiotic stress factors and erroneous management practices, including the use of heavy farm machinery to till and prepare the soil for crop cultivation, may significantly affect the productivity and conservation of cork oaks (Arosa et al. 2017). Several authors report a general degraded condition of cork oaks, known as oak decline (Branco \& Ramos 2009, Moricca et al. 2016). Good practices, such as pruning to remove dead branches and avoiding debarking stressed or damaged trees (indicators 8.2 and 8.3 , respectively), should be adopted to limit diseases and further stress conditions and to improve stand stability and productivity.

A relevant factor for conservation and management of Mediterranean woodland is fire, considering both its occurrence and recurrence (Mancini et al. 2017). In Sardinia, fire recurrence is the major damaging factor for cork oak woodlands (Ricotta \& Di Vito 2014, Salis et al. 2017), though this species has high fire resistance thanks to its thermal insulating bark and its capacity to re-sprout after fire. In fact, in the event regeneration are seriously affected and stands may be compromised (Sirca et al. 2015). We highlight the importance of fire management, with ad hoc indicators (fire management), taking into account both prevention and post-fire actions. In areas where forest fires are frequent, understory vegetation should be reduced to limit the conditions that may facilitate the shift from surface fires to dangerous crown fires (Corona et al. 2015) and cork extraction should be suspended for at least one year in burnt stands.

Cork oak seedlings and young oak trees can be damaged by grazing of wild herbivores and livestock, by competition with other tree species and by the use of farm machinery. The regeneration of cork oak deserves special attention in stand management. The indicators 5, 9.2, 9.3 consider such critical aspects, providing sustainable management solutions to harmonize the different forest and farming goals of cork oak systems.

Cork oak forests are characterized by different stand structures: in Sardinia and northeastern Spain cork oaks mainly grow of recurrent fires both gamic and agamic 
in pure and mixed stands with an average overall density of around 500 cork trees per hectare, whereas in Portugal and the rest of Spain there are often open stands (i.e., savanna-like woodlands) with densities as low as 60 cork trees per hectare. Pizzurro et al. (2010) found that stand density affects cork productivity and cork quality, the latter being higher in less dense stands. In private stands, the density can be reduced in order to achieve higher cork production levels with better quality. The proposed indicator "Maximum reduction of tree density (tree number and basal area) at forest management level" has been elaborated to limit this type of ex ploitation of cork oak stands.

Finally, for the stability and productivity of cork oak systems it is important to take into account the age/size of trees. The age/size classes proposed in this study (in dicator 9.1) are in accordance with Palma et al. (2015), reporting how forest manage ment adaptation strategies optimizing tree density could increase cork productivity un der future climate change scenarios.

\section{Conclusions}

The fate of cork oak trees, ecosystems and landscapes depend in large part on pragmatic issues of land-uses and economic tradeoffs. Yet the way people think and feel about the trees and landscapes is important as well. Ethics, cultural values and identity play a relevant role in the way people act, along with short-term economic evaluations. Socio-ecological integration, achieved by means of SFM, may make cork oak woodlands potentially more resistant to market fluctuations. Diverse socioeconomic contexts and cork oak management systems may be integrated with sustainable strategies and tools for future management scenarios in a rapidly changing world. Under such perspectives, the SFM indicators proposed and tested in the present study can support proactive management and conservation measures, in the current context of growing environmental and socioeconomic awareness.

The results of the questionnaire carried out have shown the current relevance of such issues as perceived by both experts and stakeholders. At the same time, the results of the field survey in Sardinia have highlighted that, albeit compliance with sustainability standards already largely holds for most cork oak forests, there is significant room for management improvement.

The set of indicators proposed suitably fits with the International Criteria of Small and Low Intensity Managed Forests (SLIMF), which refers to the FSC scheme, and with the Sustainable Forest Management certification Standard developed for Italian forests (PEFC Italy 2015). From this perspective, the proposed set of indicators are not only a reference for management improvement, but also provide valuable support for cork marketing strategies to- wards the general public. SFM and forest certification are strictly related aspects in the forestry sector and share the same aims: both focus on the implementation of an appropriate (sustainable) forest management that takes into account ecological, economic and social issues. Furthermore, certification aims to track the origin of forest products and represents a tool to potentially reinforce the cork oak market. Finally, it should be noted that cork oak systems can provide not only cork and nonwoody forest products, but can also support recreational and tourism activities, especially in SFM- and certified-forests (Vallejo et al. 2009), for both local people living in nearby cities and international tourists.

\section{Acknowledgements}

This work was supported by the Sardinian Region under the project "Multifunzionalità delle foreste a quercia da sughero in Sardegna" (Multifunctionality of cork oak forests in Sardinia) funded under the L.R. n. 7/2007 "Promozione della ricerca scientifica e della innovazione tecnologica in Sardegna" / Tender no. 2. We would like to thank the expert panel for contributing to the discussion of the proposed SFM indicators for cork oak forests. We are grateful to the helpful comments by two anonymous reviewers who greatly contributed to improve an earlier version of this paper.

\section{References}

Acácio V, Holmgren M (2014). Pathways for resilience in Mediterranean cork oak land use systems. Annals of Forest Science 71: 5-13. - doi: 10.1007/s13595-012-0197-0

Agnoletti M, Agrimi MG, Barbati A, Barbera G, Bovio G, Casanova P, Chirici G, Ciancio O, Corona $\mathrm{P}$, Cullotta S, Dettori S, Di Massimo G, Ferrari E, Filigheddu MR, Garfì V, Hermanin L, Iovino F, La Mantia T, La Mela Veca DS, Marchetti M, Maltoni A, Mariotti B, Masci A, Memoli A, Menguzzato G, Nocentini S, Pettenella D, Pizzurro G, Portoghesi L, Scarascia Mugnozza G, Scotti R, Secco L, Sedda L, Tani A, Veltri A (2004). Standard di buona gestione forestale per i boschi Appenninici e Mediterranei (SAM) [Forest management standards for the Appenine and Mediterranean forests]. Accademia di Scienze Forestali, Firenze, pp. 23. [in Italian]

APCOR (2015). Cork - environmental importance. Cork Information Bureau, Portuguese Cork Association (APCOR), Santa Maria de Lamas, Portugal, pp. 3-13.

Aronson J, Pereira JS, Pausas JG (2009). Cork oak woodlands on the edge. In: "Ecology, Adaptive Management, and Restoration" (Aronson J, Pereira JS, Pausas JG eds). Island Press, Washington, DC, USA, pp. 11-17.

Arosa ML, Bastos R, Cabral JA, Freitas H, Costa SR, Santos M (2017). Long-term sustainability of cork oak agro-forests in the lberian peninsula: a model-based approach aimed at supporting the best management options of the montado conservation. Ecological Modelling 343: 68-79. - doi: 10.1016/j.ecolmodel.2016.10. 008

Barberis A, Dettori S, Filigheddu MR (2003).
Management problems in Mediterranean cork oak forests: post fire recovery. Journal of Arid Environments 54 (3): 565-569. - doi: 10.1006/ jare.2002.1079

Branco M, Ramos AP (2009). Coping with pest and diseases. In: "Ecology, Adaptive Management, and Restoration" (Aronson J, Pereira JS, Pausas JG eds). Island Press, Washington, DC, USA, pp. 103-111.

Brunori A, Dini F, Noriega AB, Salazar P (2017). PEFC certification, sustainable cork production with marketing appeal. In: Proceedings of the "International Congress on Cork Oak Trees and Woodlands. Conservation, Management, Products and Challenge for the Future" (Dettori S, Filigheddu MR, Cillara M eds). Sassari (Italy) 2526 May 2017, Abstract book, pp. 71. - doi: 10.14275/978-88-907678-0-7

Bugalho $M$, Plieniinger T, Aronson J, Ellatifi $M$, Gomes Crespo D (2009). Open woodlands: a diversity of uses (and overuses). In: "Ecology, Adaptive Management, and Restoration" (Aronson J, Pereira JS, Pausas JG eds). Island Press, Washington, DC, USA, pp. 33-45.

Bugalho MN, Caldeira MC, Pereira JS, Aronson J, Pausas JG (2011). Mediterranean cork oak savannas require human use to sustain biodiversity and ecosystem services. Frontiers in Ecology and Environment 9 (5): 278-286. - doi: $10.1890 / 100084$

Camilo-Alves C, Da Clara M, De Almeida Ribeiro N (2013). Decline of Mediterranean oak trees and its association with Phytophtora cinnamomi: a review. European Journal of Forest Research 132: 411-432. - doi: 10.1007/s10342-013-0688-z

Catry FX, Moreira F, Pausas JG, Fernandes PM, Rego F, Cardilo E, Curt T (2012). Cork oak vulnerability to fire: the role of bark harvesting, tree characteristics and abiotic factors. PLoS One 7 (6): e39810. - doi: 10.1371/journal.pone.oo 39810

Cañellas I, Montero G (2002). The influence of cork oak pruning on the yield and growth of cork. Annals of Forest Science 59: 753-760. doi: 10.1051/forest:2002061

Corona P, Ascoli D, Barbati A, Bovio G, Colangelo G, Elia M, Garfì V, lovino F, Lafortezza R, Leone V, Lovreglio R, Marchetti M, Marchi E, Menguzzato G, Nocentini S, Picchio R, Portoghesi L, Puletti N, Sanesi G, Chianucci F (2015). Integrated forest management to prevent wildfires under Mediterranean environments. Annals of Silvicultural Research 39: 1-22. [online] URL: http://www.researchgate.net/publication/27107 4753

Costa A, Pereira H (2010). Influence of cutting direction of cork planks on the quality and porosity characteristics of natural cork stoppers. Forest Systems 19: 51-60. - doi: 10.5424/fs/201019101166

Costa A, Barbosa I, Roussado C, Graa J, Spiecker $H$ (2016). Climate response of cork growth in the Mediterranean oak (Quercus suber L.) woodlands of southwestern Portugal. Dendrochronologia 38: 72-81. - doi: 10.1016/j.dendro.201 6.03 .007

CPF (2014). Cork oak forests. Forest typologies and management models. Generalitat de Catalunya. Departament d'Agricultura, Ramadeira, Pesca, Alimentació i Medi Natural - Centre de la Propietat Forestal, Lleida, Spain, pp. 5-39. 
Dalla Vecchia I, Pettenella D (2017). Cork oak certification in the Mediterranean basin: state of the art and market trends. In: Proceedings of the "International Congress on Cork Oak Trees and Woodlands. Conservation, Management, Products and Challenge for the Future" (Dettori S, Filigheddu MR, Cillara M eds). Sassari (Italy) 25-26 May 2017. - doi: 10.14275/978-88907678-0-7

Dettori S, Filigheddu MR, Gutierrez M (2001). La gestione delle sugherete. La coltivazione della quercia da sughero [Cork oak management. Plantation of cork oak]. In: "Nuove metodologie per la gestione sostenibile dei sistemi forestali complessi nell'Italia meridionale" [New methodologies for the sustainable management of forest systems in southern Italy]. Accademia Italiana di Scienze Forestali, Firenze, pp. 95-110. [in Italian]

DGRF (2005). Código International de praticas subericolas. [International code of the cork oak practice]. Interreg III A Cooperación Transfrontaliza Espana-Portugal, Fondo Europeo de Desarollo Regional Iniciativa Comunitaria Interregg III, Evora, Portugal, pp. 1-13. [in Portuguese]

European Commission (2013). Communication from the Commission to the European Parliament. The Council, the European Economic and Social Committee and The Committee of the Regions, 20 September 2013.

FSC Portugal (2012). FSC standards for forest management for Portugal. FSC-STD-PRT-012012, Portugal plantation and Natural EN, Associação para uma Gestão Florestal Responsável (AGFR), Lisbon, Portugal, pp. 44-64.

INFC (2007). Le stime di superficie 2005 - Prima Parte [Estimation of Italian forest area 2005 First Part] (Tabacchi G, De Natale F, Di Cosmo L, Floris A, Gagliano C, Gasperini P, Genchi G, Scrinzi G, Tosi V eds). Inventario Nazionale delle Foreste e dei Serbatoi Forestali di Carbonio. MiPAF - Corpo Forestale dello Stato - Ispettorato Generale, CRA - ISAFA, Trento, Italy, web site [in Italian] [online] URL: http://www.infc.it

Mancini D, Barbati A, Corona P (2017). Geospatial analysis of woodland fire occurrence and recurrence in Italy. Annals of Silvicultural Research 41: 41-47. - doi: 10.12899/asr-1376

MCPF (1993). General guidelines for the sustainable management of forest in Europe. Resolution $\mathrm{H}_{1}$, Second Ministerial Conferences on the
Protection of Forests in Europe, 16-17 June 1993, Helsinki, Finland, pp. 2-5.

Moricca S, Linaldeddu B, Ginetti B, Scanu B, Franceschini A, Ragazzi A (2016). Endemic and emerging pathogens threating cork oak trees: management options for conserving a unique forest ecosystem. Plant Disease 100 (11): 21842193. - doi: 10.1094/PDIS-03-16-0408-FE

Oliveira G, Costa A (2012). How resilient is Quercus suber L. to cork harvesting? A review and identification of knowledge gaps. Forest Ecology and Management 270: 257-272. - doi: 10.1016/j.foreco.2012.01.025

Oliveira V, Lauw A, Pereira H (2016). Sensitivity of cork growth to drought events: insights from a 24-years chronology. Climatic Change 137: 261-274. - doi: 10.1007/s10584-016-1680-7

Palahi M, Mavsar R, Gracia C, Birot Y (2008). Mediterranean forests under focus. The International Forestry Review 10 (4): 676-688. - doi: 10.1505/ifor.10.4.676

Palma JHN, Paulo JA, Faias SP, Garcia-Gonzalo J, Borges JG, Tomé M (2015). Adaptive management and debarking schedule optimization of Quercus suber L. stands under climate change. Case study in Chamusca, Portugal. Regional Environmental Change 15: 1569-1580. - doi: 10.1007 /s10113-015-0818-x

PEFC Italy (2015). Criteria and indicators for sustainable forest management certification on an individual and group scale. PEFC ITA 1001-1, Italy, pp. 28. [online] URL: http://www.pefc.it/ images/stories/Documents/ITA_GFS_ENG_2015/ Annex 2 ITA 1001-1_engl.pdf

Pizzurro G, Maetzke F, La Mela Veca D (2010). Differences of raw cork quality in productive cork oak woods in Sicily in relation to stand density. Forest Ecology and Management 260: 923-929. - doi: 10.1016/j.foreco.2010.06.013

RAS (1994). Legge regionale 9 Febbraio 1994, n. 4 della Regione Autonoma della Sardegna, Disciplina e provvidenze a favore della sughericoltura e modifiche alla legge regionale 9 Giugno 1989 n. 37 “Disciplina e provvidenze a favore della sughericoltura e dell'industria sughericola" [Regional law 4 of 9 February 1994, Guidelines for cork oak plantation and changes of regional law n. 37 of 9 of June 1989 "Guidelines for cork oak plantation and cork oak sector"]. Regione Autonoma della Sardegna, Cagliari, Italy. [in Italian]

RAS (2008). Carta di uso del suolo in scala
1:25000 [Land use map at scale 1.25000]. Regione Autonoma della Sardegna, Cagliari, Italy. [in Italian] [online] URL: http://www.sardegna geoportale.it/argomenti/cartedelsuolo.html Ricotta C, Di Vito S (2014). Modeling the landscape drivers of fire recurrence in Sardinia (Italy). Environmental Management 53 (6): 1077-1084. - doi: 10.1007/s00267-014-0269-z

Ruju S (2002). Il peso del sughero. Storia e memorie dell'industria sugheriera in Sardegna (18302000) [Cork oak's weight. History and memories of cork oak sector in Sardinia (1830-2000)]. Stazione Sperimentale del Sughero, Sassari, Italy, pp. 100-102. [in Italian]

Salis M, Arca B, Alcasena-Urdiroz F, Bacciu V, Massaiu A, Bosseur F, Caramelle P, Molina-Terren D, Santoni PA, Vega-Garcia C, Spano D, Duce $P$ (2017). Recent dynamics of wildfires in Quercus suber L. woodlands in Sardinia, Corsica and Catalonia. In: Proceedings of the "International Congress on Cork Oak Trees and Woodlands. Conservation, Management, Products and Challenge for the Future" (Dettori S, Filigheddu MR, Cillara M eds). Sassari (Italy) 25-26 May 2017, Abstract book, pp. 59. - doi: 10.14275/ 978-88-907678-0-7

Sedda L, Delogu G, Dettori S (2011). Forty-four years of land use changes in a Sardinian cork oak agro-silvopastoral system: a qualitative analysis. The Open Forest Science Journal 4: 5766. - doi: 10.2174/1874398601104010057

Sirca C, Filigheddu MR, Zucca GM, Cillara M, Bacciu A, Bosu S, Dettori S (2015). Long-term researches on post fire recovery techniques of cork oak stands. In: Proceedings of the $2^{\text {nd }}$ International Congress of Silviculture "Designing the Future of the Forestry Sector". Firenze (Italy) 26-29 Nov 2014. Accademia Italiana di Scienze Forestali, Firenze, Italy, vol. 1, pp. 491496.

Vallejo RV, Aronson J, Pausas JG, Pereira JS, Fontaine C (2009). The way forward. In: "Ecology, Adaptive Management, and Restoration" (Aronson J, Pereira JS, Pausas JG eds). Island Press, Washington, DC, USA, pp. 235-242.

\section{Supplementary Material}

Tab. S1 - SFM indicators for cork oak forests proposed and tested in this study.

Link: Pollastrini_2587@supploo1.pdf 